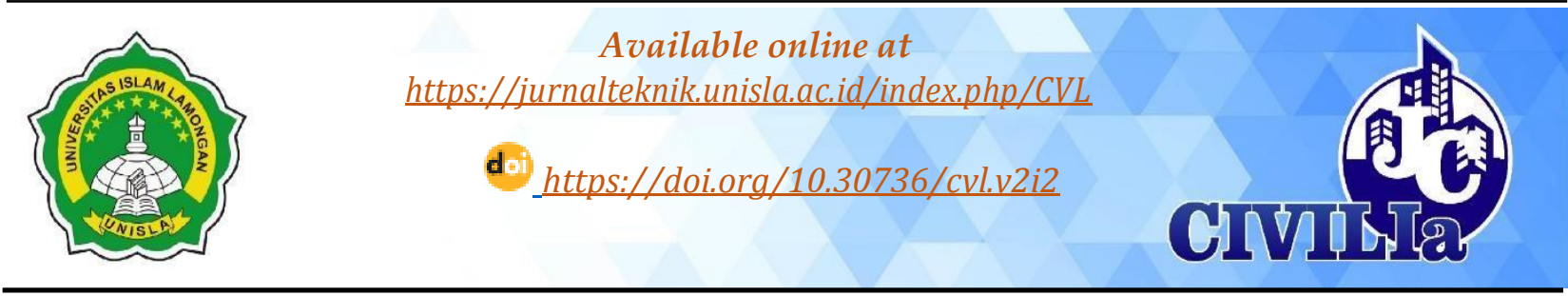

\title{
Adaptive Neuro-Fuzzy Inference System For Forecasting Traffic Volume \\ (Case Study Of National Road Km 41 Kamal)
}

Agustinus Angkoso ${ }^{1 *}$, Muhammad Shofwan Donny Cahyono ${ }^{2}$

${ }^{1 * 2,3}$ Faculty of Engineering. Civil Engineering

Email : ${ }^{1^{*}}$ agustinusangkoso@gmail.com. ${ }^{2 *}$ donnycahyono88@gmail.com

\section{A R T ICLE INFO}

\section{Article History :}

Article entry : :17-02-2021

Article revised : :31-03-2021

Article received : 27-09-2021

Keywords :

National Road KM 41 Kamal; Neuro Fuzzy; Traffic Volume;

Forecasting Methods

IEEE Style in citing this article : [Heading citation]

One, N. P., \& Second, N. P. (Year). Article Title.

Civilla : Universitas Islam

Lamongan, v(n), Start page - End page. [heading citation contents]

\section{A B S T R A C T}

The effect of the development of an infrastructure such as shopping centers, settlements, and so on is one study that is generally considered in the governance of a region. Typically, this construction has a major traffic impact. Combined with the effects of population growth, which is constantly growing every year, the flow of traffic is increasingly congested. This is because many of these people choose to own personal vehicles. Tremendous congestion would result from a road capacity that is not proportional to vehicle growth. Therefore, it is necessary to conduct research to estimate the amount of traffic that will occur so as to minimize the occurrence of traffic congestion. A traffic analysis was conducted using road traffic volume data to prevent this. This research will attempt to survey a road on National road KM 41 Kamal and use the neuro fuzzy method to forecast traffic volume. The amount of traffic that will be studied is only motorcycles. The results show that with an error percentage of $16.0793 \%$, neuro fuzzy can predict motorcycle traffic volume. It can be inferred from this that Neuro Fuzzy can forecast traffic volume on a road quite well.

Copyright (C) 2021 Agustinus Angkoso, dkk. This work is licensed under a Creative Commons

Attribution-ShareAlike 4.0 International License. Allows readers to read, download, copy, distribute, print, search, or link to the full texts of its articles and allow readers to use them for any other lawful purpose. 


\section{Introduction}

Transportation is at the heart of a city's development. This is an important sector to pay attention to because it will decide whether a city will develop. It can be seen in big cities that the transportation system organized neatly. This is because population growth will be much higher in major cities [1]. The flow of transport traffic will increase so that there will be congestion, and so on, even as the growing population of a city will increase.

The major cause is vehicle growth, which is not balanced by road growth. Therefore, the road capacity available is not balanced by the number of vehicles in the area. The growth of settlements and infrastructure has also led to congestion, besides the growth of vehicles [2]. The importance of traffic analysis in improving the performance of transport in a city lies here.

Data on the amount of use of vehicles in the region is necessary in the design of good transport. The number of vehicles going through a point or line on a specific road is the amount of vehicle traffic. Data collection on the number of vehicles that occur in a location is typically carried out using methods of survey or field observations. Traffic volume data is the data necessary for the planning, design, management and operation of a road [3][4].

In traffic observation, 3 types of vehicles are measured, specifically light vehicles, heavy vehicles and motorbikes. Here, light vehicles are 4-wheel motor vehicles, heavy vehicles are over 4-wheel motor vehicles, such as buses, trucks and others, while motorcycles are 2-wheel motor vehicles, such as motorcycles[5]. This form of vehicle will be counted every 1 hour and up to 24 hours of observations will be made. The traffic volume data will typically be observed for several days, as required for analysis calculations[6].

Road planning that is used as transportation in the long term requires this traffic volume data[7]. From this data, we can predict the number of vehicles on the road in the coming years. A variety of studies have attempted to predict an occurrence using such techniques, including fuzzy logic, linear regression, auto-regressive integrated moving average (ARIMA) neural networks, and so on.

This research attempts to approach another forecasting method, specifically neuro fuzzy. Neuro fuzzy is a method that combines neural networks with fuzzy logic[8]. This method is one way that is sometimes used to diagnose or forecast something reasonably accurate[9][10][11][12]. This research will therefore use the Neuro Fuzzy method to estimate 
the amount of traffic that will occur. It is hoped that the findings of this study will become the basis for decision-making on road planning.

\section{Literature Review}

Neuro Fuzzy or commonly called ANFIS (Adaptive Neuro-Fuzzy Inference System) is a combination of fuzzy logic and neural network. Fuzzy logic is an extended form of strict logic which has a value between High (1) and Low (0) [13]. Lotfi Zadeh discovered this fuzzy logic in 1965. The advantage of this fuzzy logic is that it can model a form of qualitative data from human knowledge where decision making is based on a rule (rule based). This qualitative data is linguistic, which in the process will be converted into fuzzy logic before being processed in rule based [14].

Meanwhile, the neural network or what is commonly called an artificial neural network is a method that is inspired by neural networks in humans [5]. Implementing this neural network is because humans can produce an action based on the experience of learning. This artificial neural network has several neurons that are placed on several layers. Each of these neurons is connected to each other and have a certain weight. This weight will be sought in the learning or training process to produce the desired output.

This combination is made because they see the concept of human thought. Humans think of vague values as fuzzy logic. This fuzzy value makes human decisions less coherent or less rigid. In neuro fuzzy conditions, we can learn this method of reasoning in a training phase (training)[15]. This is the advantage of neuro-fuzzy relative to other methods.

Neuro fuzzy has a unique structure of 5 layers in it. The shape of the structure can be seen in Figure 1 below [8].

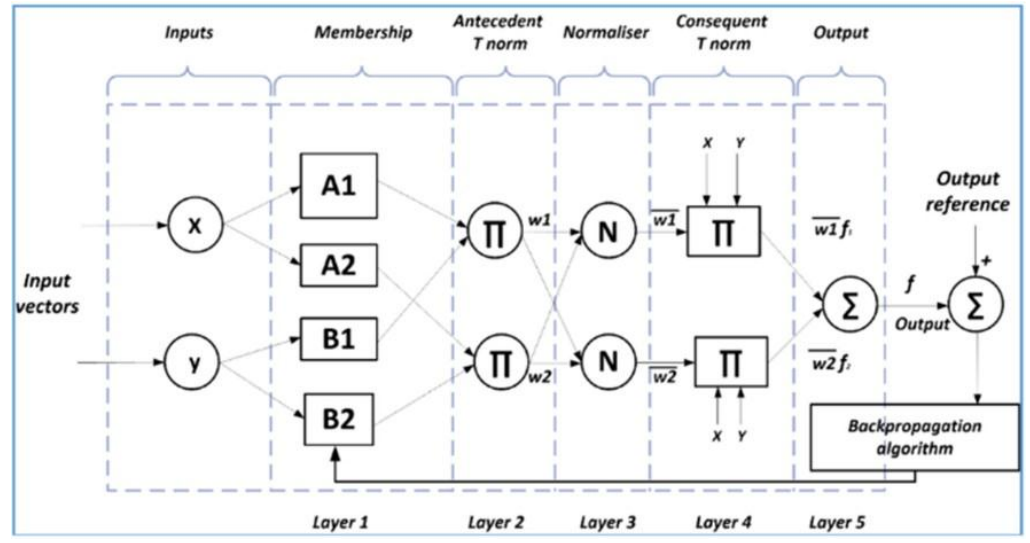

Source : Research result (2021)

Figure 1. Neuro Fuzzy Structure 
Each layer has a different mechanism. The mechanism is described as follows:

\section{Layer 1}

The function of this layer is fuzzyfication. The output at node $\mathrm{i}$ at layer 1 is denoted as $\mathrm{O}$, i. Each node in layer 1 is adaptive to the outputs shown in (1) and (2). Where $\mathrm{x}$ and $\mathrm{y}$ are the input values for nodes and $\mathrm{Ai}$ or $\mathrm{Bi}$ is a fuzzy set. So each node in layer 1 is to produce a degree of membership.

$$
\begin{aligned}
& O_{1, i}=\mu_{A i}\left(x_{1}\right), i=1,2 . \\
& O_{1, i}=\mu_{B i}\left(x_{2}\right), i=3,4 .
\end{aligned}
$$

\section{Layer 2}

Layer 2 is denoted as $\pi$. Each node in this layer calculates the activation power (firepower) of each rule as the product of all incoming inputs. The output of this layer is shown in (3).

$O_{2, i}=w_{i}=\mu_{A i}\left(x_{1}\right) \mu_{B i}\left(x_{2}\right), i=1,2$.

So,

$w_{1}=\mu_{A 1}\left(x_{1}\right) A N D \mu_{B 1}\left(x_{2}\right)$

$w_{2}=\mu_{A 2}\left(x_{1}\right) A N D \mu_{B 2}\left(x_{2}\right)$

\section{Layer 3}

Layer 3 is denoted by N. Each node in this layer is non-adaptive which functions only to calculate the ratio of the firepower in rule $i$ to the total firepower of all rules. The output of layer 3 is shown in (6).

$O_{3, i}=\bar{w}=\frac{w_{i}}{w_{1}+w_{2}}, i=1,2$

\section{Layer 4}

At this layer, each node is adaptive as a function of (13).

$O_{4, i}=-w_{i}=-w\left(p_{i} x_{1}+q_{i} x_{2}+r_{i}\right)$ 
Where $\mathrm{w} \_\mathrm{i}$ is the output layer 3 and $\left\{\mathrm{p} \_\mathrm{i}_{-} \_1+\mathrm{q} \_\mathrm{i} \mathrm{x}_{-} 2+\mathrm{r} \_\mathrm{i}\right\}$ is the parameter set in the first order Sugeno fuzzy model.

\section{Layer 5}

A single vertex is denoted by $\Sigma$. The function of this layer is to combine all outputs from layer 4 as shown in (14).

$$
O_{5, i}=\sum_{i} \overline{w f}_{i}=\frac{\sum_{i} w_{i} f_{i}}{\sum_{i} w_{i}}
$$

As explained, the traffic data obtained is traffic data for various vehicles, such as motorbikes, sedans, jeeps, small buses, large buses, tangka trucks, and so on. In this study, the traffic data taken is only motorbike traffic data, both as motorbikes, moped or 3-wheeled bicycles. year to year.

\section{Research Method}

This study is using road traffic data. This road traffic data contains the number of vehicles passing through a road at a certain time. Vehicles that are counted have various types, ranging from motorbikes, trucks, cars, and so on.

This research took a case study on National road KM 41 Kamal. The location of the road shows in Figure 1 below.

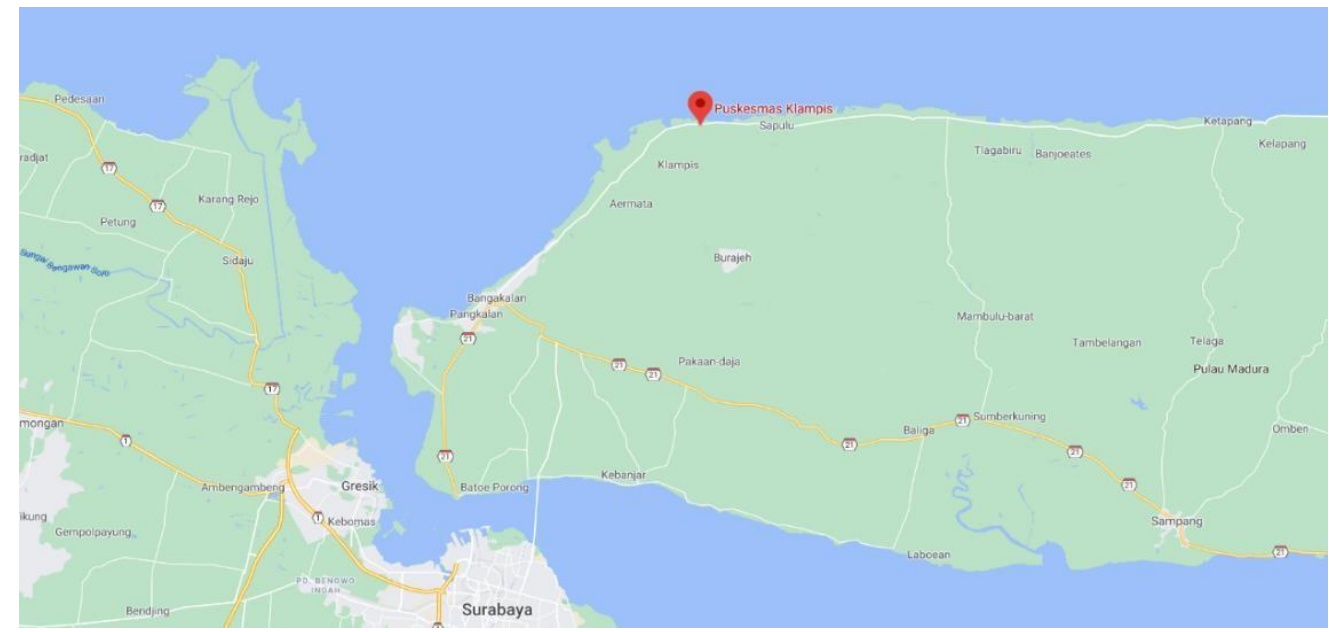

Source : Research result (2021)

Figure 1. Location of National Road KM 41 Kamal 
This traffic data is obtained by conducting a survey directly in the area. This survey was conducted by 5 people who would gentian record the number of various types of vehicles passing on the road. This survey performed for 1 week, starting from 11 May 2018 to 17 May 2018.

The recording is carried out for 1 week for 24 hours where the number of vehicles will be tabulated per 1 hour, so that from this data we can see how many vehicles for a certain type pass through the road and the accumulation of vehicles occurs at what time. This is very important to know as material for the road load analysis. In addition, on that road, the recording was carried out 2 times in different traffic directions. This is because on this road, traffic is divided into 2, traffic on the left side of the road and vehicle traffic on the right. It is very important to note these matters as material for the load analysis of the road. In this study, the types of vehicles to be analyzed are limited to motorbikes only. The results of the road traffic survey shown in Table 1 below.

Table 1. The Volume of Motorcycles on the KM41 Kamal National Road

\begin{tabular}{ccccccccc}
\hline No & Time & & \multicolumn{7}{c}{ Mei 2018} \\
& & 11 & 12 & 13 & 14 & 15 & 16 & 17 \\
\hline 1 & $06.00-07.00$ & 464 & 469 & 212 & 459 & 398 & 471 & 441 \\
2 & $07.00-08.00$ & 322 & 380 & 256 & 325 & 306 & 332 & 302 \\
3 & $08.00-09.00$ & 523 & 453 & 278 & 431 & 490 & 433 & 483 \\
4 & $09.00-10.00$ & 665 & 476 & 241 & 658 & 588 & 305 & 566 \\
5 & $10.00-11.00$ & 480 & 388 & 226 & 480 & 429 & 481 & 418 \\
6 & $11.00-12.00$ & 96 & 398 & 253 & 94 & 96 & 92 & 154 \\
7 & $12.00-13.00$ & 293 & 402 & 195 & 287 & 237 & 299 & 293 \\
8 & $13.00-14.00$ & 284 & 368 & 171 & 286 & 227 & 301 & 284 \\
9 & $14.00-15.00$ & 308 & 250 & 156 & 308 & 243 & 313 & 308 \\
10 & $15.00-16.00$ & 506 & 344 & 316 & 494 & 479 & 489 & 502 \\
11 & $16.00-17.00$ & 448 & 542 & 300 & 445 & 397 & 453 & 365 \\
12 & $17.00-18.00$ & 214 & 308 & 365 & 214 & 187 & 222 & 188 \\
13 & $18.00-19.00$ & 418 & 337 & 257 & 410 & 385 & 428 & 321 \\
14 & $19.00-20.00$ & 317 & 306 & 201 & 318 & 256 & 333 & 279 \\
15 & $20.00-21.00$ & 176 & 182 & 81 & 153 & 162 & 175 & 147
\end{tabular}


Civilla : Jurnal Teknik Sipil Universitas Islam Lamongan Volume 06 Number 2 Year 2021

\begin{tabular}{ccccccccc}
16 & $21.00-22.00$ & 96 & 104 & 58 & 80 & 74 & 89 & 86 \\
17 & $22.00-23.00$ & 67 & 73 & 28 & 66 & 64 & 73 & 54 \\
18 & $23.00-24.00$ & 35 & 21 & 18 & 36 & 28 & 45 & 35 \\
19 & $24.00-01.00$ & 21 & 36 & 11 & 21 & 13 & 29 & 23 \\
20 & $01.00-02.00$ & 18 & 18 & 16 & 14 & 12 & 20 & 15 \\
21 & $02.00-03.00$ & 14 & 12 & 30 & 9 & 11 & 13 & 8 \\
22 & $03.00-04.00$ & 14 & 10 & 91 & 12 & 9 & 15 & 14 \\
23 & $04.00-05.00$ & 64 & 46 & 201 & 63 & 58 & 69 & 78 \\
24 & $05.00-06.00$ & 216 & 147 & 336 & 206 & 166 & 213 & 191 \\
\hline
\end{tabular}

Source : Research Results (2021)

\section{Results and Discussions}

\subsection{Neuro Fuzzy Training}

In the Neuro-Fuzzy method, there are 2 stages, namely, the training stage and the testing phase. The training stages are carried out using past data. In this study, there was traffic volume data for 7 days, from 11 May 2018 to 17 May 2018. This data will be divided into 2, specifically data for training and data for testing. This training data will use traffic volume data from 11 May 2018 to 16 May 2018.

At this stage, the first thing to do is determine the Neuro-Fuzzy structure to use. This structure is influenced by 3 things, including:

1.Input membership function

2.Type of output membership function

\section{Total membership function input}

The Neuro-Fuzzy structure made in this study has an input as a clock and an output in the numbers form of motorbikes passing National Road KM 41 Kamal. In this Neuro-Fuzzy structure, a membership function is determined as a Gauss function with 10 membership function inputs. In addition, this structure uses a type of linear membership function from the output side of this network[16].

These data will be entered in MATLAB 2014a to form the Neuro-Fuzzy structure. After entering the data, the Neuro-Fuzzy structure in MATLAB 2014a will look like in Figure 3 below.

From the test in table 1, it will be known the error rate for forecasting motorcycle traffic that passed the road on May 17, 2018. The Neuro Fuzzy Network used in this study, the structure of which can be seen in Figure 2 below. 


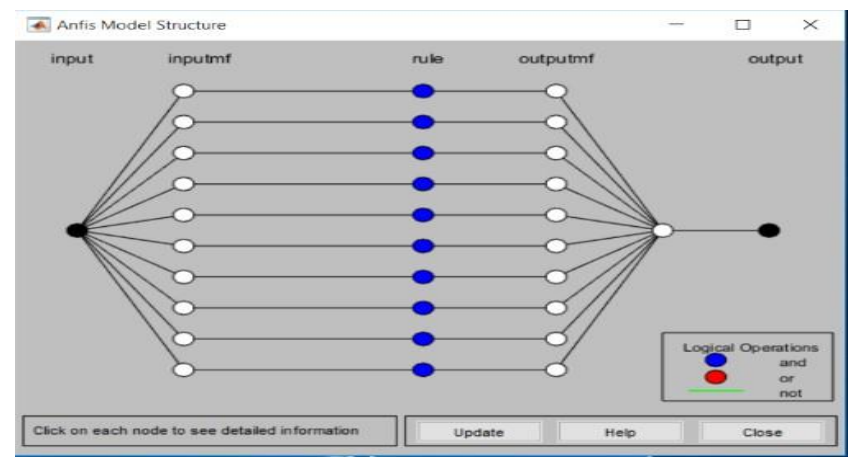

Source : Research Results (2021)

Figure 3. Neuro Fuzzy Structure

In determining the Neuro Fuzzy structure to be established, we must first decide on the following three things: the type of membership input function, the type of membership output function, and the number of membership input functions[17].

As can be seen in Figure 2, Neuro Fuzzy has an input in the form of a clock and an output in the form of the number of motorcycles passing through the road[18][19]. In this Neuro Fuzzy structure, it has 10 membership function inputs with the form of Gauss input membership function. From the output side, this structure uses a type of linear membership function[20].

After these parameters have been determined, they will then be entered into MATLAB 2014a. Then the process after that will move to the training or traning process will be carried out the training process or training as shown in Figure 3 below.

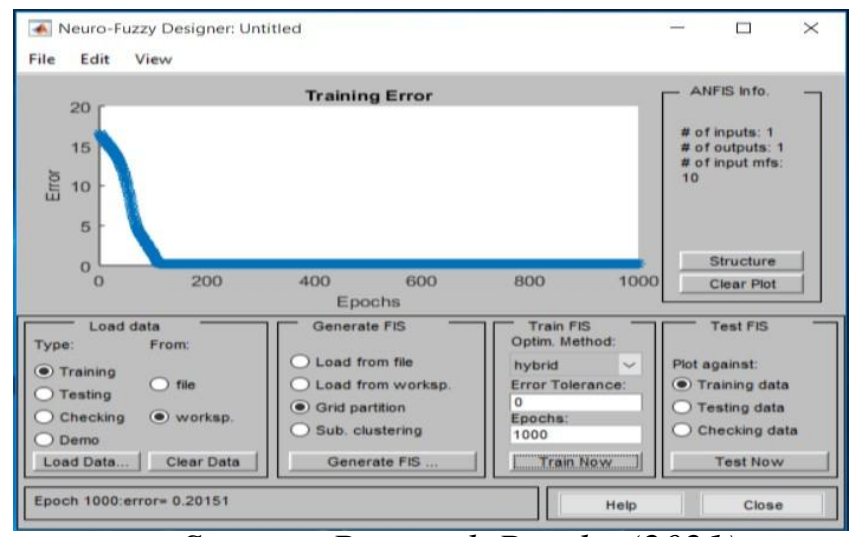

Source : Research Results (2021)

Figure 4. Neuro Fuzzy Training Process

This training process will be repeated up to 1000 times or what is commonly called 1000 epoch. Figure 3 illustrates that the training process resulted in a fairly small error rate of 0.20151 . 


\subsection{Neuro Fuzzy Testing}

After the training process is performed, the Neuro Fuzzy network will be tested using motorbike traffic volume data on May 17, 2018. Input data is entered into the network and will produce output (output). This value will be compared with the original (yreal) value of 24 , which is the data on May 17, 2018. The difference between the two data is the error rate generated by this Neuro Fuzzy network. The value of this error or error is calculated using the equation below.

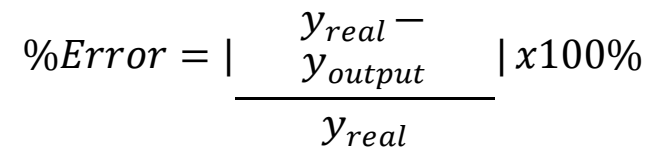

Each of these errors will be calculated and summarized in a table. The results show in Table 2 below.

Table 2. Neuro Fuzzy Testing

\begin{tabular}{|c|c|c|c|c|}
\hline No & Time & Youtput & $\mathrm{y}_{\text {real }}$ & \%error \\
\hline 1 & $06.00-07.00$ & 412 & 441 & 6.575964 \\
\hline 2 & $07.00-08.00$ & 320 & 302 & 5.960265 \\
\hline 3 & $08.00-09.00$ & 435 & 483 & 9.937888 \\
\hline 4 & $09.00-10.00$ & 489 & 566 & 13.60424 \\
\hline 5 & $10.00-11.00$ & 414 & 418 & 0.956938 \\
\hline 6 & $11.00-12.00$ & 172 & 154 & 11.68831 \\
\hline 7 & $12.00-13.00$ & 286 & 293 & 2.389078 \\
\hline 8 & $13.00-14.00$ & 273 & 284 & 3.873239 \\
\hline 9 & $14.00-15.00$ & 263.1 & 308 & 14.57792 \\
\hline 10 & $15.00-16.00$ & 437.9 & 502 & 12.76892 \\
\hline 11 & $16.00-17.00$ & 431 & 365 & 18.08219 \\
\hline 12 & $17.00-18.00$ & 252 & 188 & 34.04255 \\
\hline 13 & $18.00-19.00$ & 373 & 321 & 16.19938 \\
\hline 14 & $19.00-20.00$ & 289 & 279 & 3.584229 \\
\hline 15 & $20.00-21.00$ & 155 & 147 & 5.442177 \\
\hline 16 & $21.00-22.00$ & 84.06 & 86 & 2.255814 \\
\hline 17 & $22.00-23.00$ & 61.76 & 54 & 14.37037 \\
\hline 18 & $23.00-24.00$ & 31.46 & 35 & 10.11429 \\
\hline
\end{tabular}


Civilla : Jurnal Teknik Sipil Universitas Islam Lamongan Volume 06 Number 2 Year 2021

$19 \quad 24.00-01.00$

21.42
ISSN (Online) 2620-7222

ISSN (Print) 2503-2399

23

6.869565 
Civilla : Jurnal Teknik Sipil Universitas Islam Lamongan

Volume 06 Number 2 Year 2021

$\begin{array}{lll}20 & 01.00-02.00 & 16.49\end{array}$

$21 \quad 02.00-03.00$

14.7

25.08

84.08

213.9

Average
9.933333

83.75

79.14286

7.794872

11.98953
191

From this test, it can be seen that the average error generated by Neuro-Fuzzy is 16.0793

$\%$. This section contains (concise form) data analysis and interpretation of results. Interpretation of results using theories from articles as used. The descriptions are given include theoretical, implicative, and managerial, or practical.

\section{Conclusion and Suggestion}

This research tries to predict the traffic volume that will occur on National road KM 41 Kama. This study uses Neuro Fuzzy in its forecasting. The data used is primary data taken through surveys. The data contains traffic volume for 7 days on the road where 6 days of data is used for the neuro fuzzy network training process, while the 1day data is used for testing the neuro fuzzy network. The results show that accccneuro fuzzy can predict traffic volume with an error rate of $16.0793 \%$. In summary, neuro fuzzy is a fairly suitable method in predicting the traffic volume on National road KM 41 Kamal.

\section{Acknowledgements}

Praise be to the presence of God Almighty, because for His blessings and mercy, this research has been completed. In addition, the authors also express their deepest gratitude to Widya Kartika University for helping in the completion of this research.

\section{References}

[1] M. Handajani, “Analisis Pengaruh Struktur Kota - Sistem Transportasi - Konsumsi BBM Kota-Kota Di Jawa,” J. Tek. Sipil dan Perenc., vol. 2, no. 12, hal. 101-110, 2010.

[2] W. Widodo, N. Wicaksono, dan Harwin, “Analisis Volume, Kecepatan, dan Kepadatan Lalu Lintas dengan Metode Greenshields dan Greenberg," J. Ilm. Semesta Tek., vol. 15, no. 2, hal. 178-184, 2012. 
[3] W. Widayani, P. Purwanto, dan D. Sutisnanto, "Survei Kepadatan Arus Lalu Lintas di Persimpangan Penceng Jalan RA. Rukmini, Kecapi Kebupaten Jepara,” Rev. Civ. Eng., vol. 1, no. 1, hal. 19-24, 2017.

[4] T. E. Naskah, "Teori analisis deskriptif," 2017.

[5] D. Saepuloh, M. Ramdhan, R. Bramawanto, dan S. Suryo Sukoraharjo, "Metode Adaptive Neuro Fuzzy Inference System Pada Aplikasi Sistem Cerdas Pendugaan Produksi Garam,” J. Kelaut. Nas., vol. 14, no. 2, hal. 125-134, 2019.

[6] A. Faiz dan H. Prajitno, "Analisis Perkembangan Volume Lalu Lintas dan Manfaat Langsung Sebelum dan Sesudah Operasionalisasi Jembatan Suramadu,” J. Apl. Tek. Sipil, vol. 14, no. 2, hal. 69-76, 2016.

[7] E. Evanita, E. Noersasongko, dan R. A. Pramunendar, "Prediksi Volume Lalu Lintas Angkutan Lebaran Pada Wilayah Jawa Tengah Dengan Metode K-Means Clustering Untuk Adaptive Neuro Fuzzy Inference System (Anfis)," Simetris J. Tek. Mesin, Elektro dan Ilmu Komput., vol. 7, no. 1, hal. 199, 2016.

[8] U. Hani'ah, R. Arifudin, dan E. Sugiharti, “Implementasi Adaptive Neuro-Fuzzy Inference System (ANFIS) untuk Peramalan Pemakaian Air di Perusahaan Daerah Air Minum Tirta Moedal Semarang,” Sci. J. Informatics, vol. 3, no. 1, hal. 76-87, 2016.

[9] E. A. Ardiansyah, R. Mardiati, dan A. Fadhil, “Aplikasi Peramalan Kebutuhan Beban Listrik Menggunakan Metode Adaptive Neuro Fuzzy Inference System (ANFIS),” TELKA - Telekomun. Elektron. Komputasi dan Kontrol, vol. 3, no. 1, hal. 36-48, 2017.

[10] M. I. Azhar dan W. F. Mahmudy, "Prediksi Curah Hujan Menggunakan Metode Adaptive Neuro Fuzzy Inference System (ANFIS)," J. Pengemb. Teknol. Inf. dan Ilmu Komput., vol. 2, no. 11, hal. 4932-4939, 2018.

[11] A. Dianto dan A. Pranolo, "Prediksi Laju Pertumbuhan Penduduk Di Kabupaten Sleman Dengan Metode Adaptive Neuro-Fuzzy Inference System (ANFIS) Dan Metode Sugeno," JSTIE (Jurnal Sarj. Tek. Inform., vol. 6, no. 3, hal. 1-7, 2018.

[12] N. Nikentari, M. Bettiza, dan H. Sasty Pratiwi, "Prediksi Kecepatan Angin Menggunakan Adaptive Neuro Fuzzy (ANFIS) dan Radial Basis Function Neural Network (RBFNN),” J. Edukasi dan Penelit. Inform., vol. 4, no. 1, hal. 70-75, 2018.

[13] B. Fatkhurrozi, M. A. Muslim, dan D. R. Santoso, "Penggunaan Artificial Neuro Fuzzy Inference Sistem (ANFIS) dalam Penentuan Status Aktivitas Gunung Merapi,” J. 
EECCIS, vol. 6, no. 2, hal. 113-118, 2012.

[14] J. Kusanti dan S. Hartati, "Identifikasi Gangguan Neurologis Menggunakan Metode Adaptive Neuro Fuzzy Inference System (ANFIS)," IJCCS (Indonesian J. Comput. Cybern. Syst., vol. 9, no. 2, hal. 187-196, 2015.

[15] M. Sihombing dan L. Andayasari, "Determinan Persalinan Seksio Sesarea Pasien Kelas Tiga Di Dua Rumah Sakit Di Jakarta Tahun 2011,” J. Kesehat. Reproduksi, vol. 6, no. 3, 2016.

[16] F. D. Harijanto, K. Kuntjoro, S. Saptarita, dan S. K. Aziz, “Analisis Pola Hujan dan Musim di Jawa Timur Sebagai Langkah Awal Untuk Antisipasi Bencana Kekeringan,” J. Apl. Tek. Sipil, vol. 10, no. 2, hal. 95, Agu 2012.

[17] K. Kuntjoro, C. Anwar, P. Pudiastuti, F. D. Harijanto, dan S. Sungkono, "Inisiasi Perkiraan Arah Pergerakan Alur Sungai," J. Apl. Tek. Sipil, vol. 11, no. 2, hal. 47, Agu 2013.

[18] P. Magister, T. Elektro, U. Brawijaya, dan F. Teknik, "Implementasi Adaptive NeuroFuzzy Inference System (ANFIS) pada Pengaturan Kecepatan Motor Sistem Stabilized Peluncur Roket Untuk Persenjataan TNI,” 2009.

[19] N. Puspitasari dan Haviluddin, "Penerapan Metode K-Means Dalam Pengelompokkan Curah Hujan,” Semin. Nas. Ris. Ilmu Komput. (SNRIK ), vol. 1, no. March 2017, hal. 2-7, 2016.

[20] E. N. D. R. A. P. Evanita, "PREDIKSI VOLUME LALU TENGAH DENGAN METODE K-MEANS CLUSTERING UNTUK ADAPTIVE NEURO,” SIMETRIS, vol. 7, no. 2252-4983, 2017. 